\title{
A Review of Green Consumer Behavior Based on the Social Perspective
}

\author{
Dandan Lin, Haiquan Chen \\ School of Management, Jinan University, Guangzhou, China \\ Email: m13247663630@163.com
}

How to cite this paper: Lin, D.D. and Chen, H.Q. (2016) A Review of Green Consumer Behavior Based on the Social Perspective. Theoretical Economics Letters, 6, 1088-1095. http://dx.doi.org/10.4236/tel.2016.65104

Received: September 16, 2016

Accepted: October 8, 2016

Published: October 11, 2016

Copyright () 2016 by authors and Scientific Research Publishing Inc. This work is licensed under the Creative Commons Attribution International License (CC BY 4.0).

http://creativecommons.org/licenses/by/4.0/

(c) (i) Open Access

\begin{abstract}
The significance of the research on green consumption behavior is not only to reveal the laws of green consumption behavior, but also to provide useful suggestions for the promotion of green consumption behavior. Therefore, the topic is of significance. This paper adopts bibliometric method to probe into the research findings of green consumption referenced by China National Knowledge Infrastructure (CNKI). In recent years, the study about green consumption has been made both at home and abroad, mainly focusing on the connotation, characteristics of green consumption, factors influencing green consumption behavior and green consumption development strategies, etc. But as far as the present state of study is concerned, there are few scholars study the mechanism of the green consumption behavior from the perspective of social comparison and point out that future research should highlight the multidisciplinary research perspective. Besides, empirical analysis tool should be strengthened in the research to detect the mechanism of green consumption behaviors.
\end{abstract}

\section{Keywords}

Green Consumption, Social Comparison Orientation, Literature Review

\section{Introduction}

In recent years, the haze weather, and water pollution has placed a great negative impact and painful results on people. And the green consumption is the key to solve the environmental crisis. "Guidance on the promotion of green consumption" also reflects the distorted consumption mode which has caused serious environmental problems in China. Vice Minister of Commerce Yan Gao pointed out that investment in energysaving and environment protection will reach 17 trillion Yuan [1]. In this context, more and more enterprises began to realize the importance and necessity of managing the 
green consumption mechanism. Promote and comply with the demand of green consumption is not only an important means to enhance the competitiveness of enterprises, but also the key to solve the environmental crisis. Thus, [2] green consumption behavior research becomes one of the important and lasting concern topics at present. The purposes of this paper are to provide a reference and new research perspective on green consumption for the scholars at home in the future, to develop and enrich study on mechanism of green consumption behavior, and to guide Chinese enterprises, which has important theoretical and practical significance.

\section{Research Progress of Green Consumption}

\subsection{Research Status of Green Consumption at Home and Abroad}

At present, a growing number of scholars at home and abroad has been to study the green consumption. Objectively, [3] it has experienced the transition from macro to micro in the process of continuous adjustment. The development process of green consumption can be divided into of three stages: enlightenment in the Mid late twentieth Century, enrichment at the end of the twentieth Century, all-round development in the twenty-first Century. Scholars concentrate on the concept definition of green consumption, the factors influencing green consumption and constraint factors analysis and discussion about guidance strategies at present.

\subsubsection{Connotation of Green Consumption}

Green consumption research began in the 1940s. However, there is no integrated system of green consumption concept [4]. One of foreign scholar, Peattie pointed out that the green consumption is environment-friendly consumption behavior to reduce the pressure of resources and environment, including the field of personal behavior, such as the purchase of Recyclable products; Carlson, Grove and Kangun believed green consumption is that consumers consider the impact of the consumption on the environment in the greatest degree, taking into account the interests of individual and society as far as possible in the purchase process. Roozen De Pelsmacker argued that green consumption includes the purchase, use and disposal behavior. In Johanna study, green consumption refers that individual concerns the consumer behavior consequences in the consumption process, where the people possess high sense of social responsibility, which is a specific consumption behavior and John points out the green consumption is that people reduce purchase frequency as much as possible, and are preferred with recycled product.

Shijie Yin defined the green consumption as the standard that people set for green consumption products, including High-quality [5], Beneficial to the body and nondrug in the specific natural environment. The Chinese consumers' association gave the more authoritative definition of green consumption in 2001. That definition of green consumption is: Firstly, advocate consumer to choose the products which is contamination free or healthy to public; Secondly, pay attention to Disposal of garbage in the process of consumption, Avoiding pollution; Thirdly, guide the consumer consumption 
idea to pursue comfortable and healthy life. At the same time, pay attention to environmental protection, save resources and energy, and realize sustainable development.

Thus, according to the literature review at home and abroad, the study adopts the definition of the green consumption Roozen and De Pelsmcker pointed out, that is acquisition of environment friendly green products, including Recyclable products, energy-saving products and organic products.

\subsubsection{The Relevant Theories of Green Consumption}

Although the majority of consumers are interested in buying green products, the consumer behavior is not consistent with the positive attitude [6] which reflects the social dilemmas, namely the individual is in a contradictory dilemma between individual and group interests. According to the market equilibrium theory, when the environmental attributes of green product are heavier, its functional attributes may reduce, or consumer need a high price to buy it. Cost of changing the original habit (such as money, time, or the quality of the products) is higher. And [7] it is more socially useful in the long term (such as enjoy comfortable environment, reduce usage of resource). If the individual against the green consumption, it means that the person chooses individual interests and gives up the group interest. Therefore, [8] green consumption is a kind of reflection of social dilemma, it forced consumers to weigh between individual interests and group interests.

However, according to the costly signaling theory, when green products have higher premiums, consumers will choose to sacrifice self interests and to purchase green luxury products. At the same time, according to the theory of competitive altruism, green consumption can help individuals to enhance their own reputation, and make them more willing to pay more money for green product. Therefore, green consumption is considered to be synthesis of the self-interest and altruism driven.

\subsubsection{Motivations of Green Consumption}

There are four motivations in the current researches on the green consumption.

To pursue health [9]. The fact that Environmental pollution is increasingly serious threaten people's health. The awareness of environmental protection has been continuously strengthened, and the pursuit of health has become an important target for consumption production.

To show the status of themselves. To some extent, purchasing green products with high price means that consumers are willing and able to sacrifice individual interest for the interest of the group. And [10] it also shows their consumption quality, taste and social status, so as to make them easier to win social recognition and good reputation.

Eager to be recognized. In order to narrow the distance with the desired group, and even become one of its members, [11] individuals chooses to buy the products that group identity. So, the desire of chasing the upper class life and high grade will strongly stimulate the consumers who possess purchasing power or some people who do not have the purchasing power to do green consumption.

To follow the public. When buying green products becomes a consumer fashion, [12] 
it is more likely to follow the public in the pursuit of "fashion", thereby promoting green consumption.

\subsubsection{Existing Research Framework of Green Consumption}

Green consumption research began in 1940s, the study is not yet mature, mainly as follows:

One is the consumer characteristics [13], including demographic characteristics, psychological variables and integrated model. This part of research is fragmented, because different scholars have different definitions of green consumption, and the use of inconsistent measurement methods. Thus, it reduces the comparability between the variables, and scholars did not attempt to explore the generality in a different green consumption situation.

Two is the factors influencing green consumption, including the consumer factors [14], product factors, external intervention and promotional factors. This part of the research is mainly based on the experimental method, study the causal relationship between variables, trying to find a way to improve consumer green consumption intention and behavior. Scholars at home and abroad often set a variety of green consumption situation in the study to try to dig essence and generality between different forms of green consumption, and to integrate different green consumption situation.

Three is the psychological mechanism, including consumer factors, products, and situational factors, measurement methods and other factors. There is no fixed methodology in this part of research. But survey method, experimental method and interview method all have been involved, [15] mainly focused on the reason why there are gaps in the green consumption attitude and behavior.

Four is the restricting factors. Although, green consumption is regarded as one of the best consumption patterns, to completely replace the traditional linear consumption patterns also faces a series of institutional barriers. There are three main constraint factors in China, including price restriction and market demand restriction and consumption environment restriction.

\subsection{The Relationship between Social Comparison Tendency and Green Consumption}

\subsubsection{The Meaning of Social Comparison Tendency}

Pro-social behavior includes all the behavior which is beneficial to the society and has a positive effect on the public. Green consumption is a kind of pro-social behavior which was seen as synthesis driven by the individual interests and other people's interests (such as opposed harm others' health and destroy the air pollution of the global climate) [16]. Social comparison tendency refers to that the individual reflect a kind of personality traits in the social demand. According to the individual comparing the difference between the intensity, frequency, consumers are divided into high social comparison tendency and low social comparison tendency [17]. The tendency of social comparison is higher, they more prefer to associate others events with their own evens, especially more sensitive to interpersonal influence, and more willing to help 
others in need [18]. Thus, they pay more attention to their own choice that has impact on the surrounding environment, which promotes the further green consumption.

\subsubsection{The Factors Influencing Green Consumption Based on the Theory of Social Exchange}

Scholars just started studying the influence mechanism of green consumer behavior from the perspective of social comparison in recent years, and few domestic scholars study in this perspective [19]. Specifically, [20] everyone wants to maximize the ratio of pay and income, including material reward (for example, the items or money), and non-material incentives (socialidentity, reputation). Based on this, the green consumption is affected by the following factors: one is the collective behavior. Green consumption is not only the individual voluntary behavior, but also the result of the collective game. The second is to share value. Social exchange theory emphasized that share value is a driving force that people interact on a micro level. And green consumption can be divided into egoism, altruism behavior and earth's ecological behaviors from the micro level [21]. The study found that altruism, egoism and earth ecological and environmental concerns have a significant effect. The third is emotional satisfaction. To explore the relationship between the green consumption and the value of nonmoney factors, McCarty found that it has a positive impact on green consumption attitude and behavior, and make the person feel satisfied when interacting with natural.

Buunk Nauta and Molleman argued that social comparison is closely related to environmental behavior. In the face of limited earth resources, compared with people who have idea comparison tendency, the people who have ability comparison tendency consider more impact of their choices on the environment [22], pay attention to others' reactions to the behavior, and will try to balance the interests of others and social interests. At the same time, they are more willing to bear the responsibility of protecting the environment, so they are more likely to implement green consumption.

\section{The Comparison of Research at Home and Abroad}

Throughout studies of green consumption at home and abroad, the study find that there has been relatively mature about green consumption at abroad. Scholars proposed and discussed the concept and connotation of green consumption, analyze the significance of green consumption, green consumption behavior from the perspective of philosophy, economics, ecology and so on. In particular, they probed into mechanism of green consumer behavior from the perspective of sociology, and use the Likertt scale method, structural equation model and regression analysis of quantitative research methods to research factors influencing the green consumption behavior intention and actual behavior. But a lot of scholars don't reach an agreement on these results, especially the influence of the objective factors on green consumption consumer, which is different and even contradictory. 
Although studies of green consumption at home is later than abroad, it has developed rapidly at present [23]. From the current research status and trends, there just is a little difference between home and abroad. Scholars at home also do a lot of work about definition, meaning, constraint factors analysis and guidance strategy in of the green consumption. But most of these studies are not system, they neither put forward their green consumption behavior to support research, empirical research on foreign TPB model based on the theory of planned behavior nor is also persuasive. All kinds of research has certain limitation, and doesn't have unified conclusion. There are mainly qualitative research on Existing study, lack of quantitative research. The design of the scale and the process of investigation lack conviction because there is no reliable theoretical model as guidance. Thus, it eventually lead that quantitative research can only obtain the conclusion of qualitative research. In addition, few domestic scholars explain its mechanism of pro-social behavior from the perspective of social comparison, and [24] further to discuss the influence mechanism of green consumer behavior.

Based on this, this paper analyzes main content about the behavior of green consumption at home and abroad and the weakness of the past studies, in order to provide the direction for the study of green consumption in the future, and to promote the development of green consumption research at home.

\section{Limitations and Suggestions for Future Research at Home}

The limitations of this study are as follows:

Firstly, it lacks theoretical research on green consumption. And the empirical study of psychological mechanism is extremely scarce. Secondly, there is few of research on pro-social behavior and mechanism, only a few literature refers to the influence of social comparison on pro-social behavior, and just is concentrated on the parallel comparison more. Thirdly, the research on influence of internal group identification on consumer behavior mostly refers to foreign achievements; the applicability remains to be tested in different situation.

Fourthly, participating in pro-social behavior can improve its reputation; however, scholars rarely discussed the relationship between green consumption and face consciousness.

According to the current research status and existing problems, the scholars could study how the social comparison tendency affect green consumption decision in the future study. On the one hand, the study could probe into the green consumption by increasing two dimensions (use behavior and disposal behavior) to enrich the formation mechanism of green consumption. On the other hand, to subdivide the green product types consumers consume. The mechanism of the effect remains to further research and so on. The analysis of these problems will not only enrich and develop study on the mechanism of effect of the social comparative on green consumption, but also help the enterprise in China to promote green products, which has important theoretical and practical significance [25]. 


\section{References}

[1] Li, J.X. (2006) The Influence Factors of Green Purchasing Analysis and Enlightenment. Journal of Changsha Polytechnic to Learn Quote: Social Science Edition, 11, 70-81.

[2] Gupta, S. and Ogden, D.T. (2009) To Buy or Not to Buy? A Social Dilemma Perspective on Green Buying. Journal of Consumer Marketing, 26, 376-391.

[3] Chan, R. and Lau, L. (2009) Antecedents of Green Purchases: A Survey in China. Journal of Consumer Marketing, 17, 338-357. http://dx.doi.org/10.1108/07363760010335358

[4] Glig, A., et al. (2005) Green Consumption or Sustainable Lifestyles? Identifying the Sustainable Consumer. Futures, 13, 81-104.

[5] Roozen, T.M. and De Pelsmacker, P. (2000) Polish and Belgian Consumers' Perception of Environmentally Friendly Behavior. Journal of Consumer Studies and Home Economics, 24, 9-21. http://dx.doi.org/10.1046/j.1365-2737.2000.00114.x

[6] Buunk, A.P. and Gibbons, F.X. (2007) Social Comparison: The End of a Theory and the Emergence of a Field. Organizational Behavior and Human Decision Processes, 102, 32-42. http://dx.doi.org/10.1016/j.obhdp.2006.09.007

[7] Ajzen, I. (2001) The Theory of Planned Behavior. Organizational Behavior and Human Decision Processes, 50, 179-211. http://dx.doi.org/10.1016/0749-5978(91)90020-T

[8] Tanner, C. and Kast, S.W. (2003) Promoting Sustainable Consumption Determinants of Green Purchases by Swiss Consumers. Psychology and Marketing, 20, 883-902. http://dx.doi.org/10.1002/mar.10101

[9] Marguerat, D. and Cestre, G. (2004) Determining Ecology-Related Purchase and Postpurchase Behaviors Using Structural Equations. Institute University Management International (IUMI), Working Paper, 12, 1-24.

[10] Frick, J., Kaiser, F.G. and Wilson, M. (2004) Environmental Knowledge and Conservation Behavior: Exploring Prevalence and Structure in a Representactive Sample. Personality and Individual Differences, 37, 1597-1613. http://dx.doi.org/10.1016/j.paid.2004.02.015

[11] Chen, Y.R., Brockner, J. and Chen, X.P. (2002) Individual-Collective Primacy and In-Group Favoritism: Enhancement and Protection Effects. Journal of Experimental Social Psychology, 38, 482-491.

[12] Griskevicius, V., Tybur, J.M. and van den Bergh, B. (2010) Going Green to Be Seen: Status, Reputation, and Conspicuous Conservation. Journal of Personality and Social Psychology, 98, 392-404. http://dx.doi.org/10.1037/a0017346

[13] He, Z.Y. and Shao, Q. (2004) Study on Green Consumer Lifestyle Characteristics. Nankai Management Review, 7, 4-10.

[14] Mainieri, T., Barnett, J. and Oskamp, S. (1997) Green Buying: The Influence of Environmental Concern on Consumer Behavior. Journal of Social Psychology, 137, 189-204. http://dx.doi.org/10.1080/00224549709595430

[15] Li, J.X. (2006) The Analysis and Enlightenment of Factors Influencing Green Purchasing. Journal of Changsha Polytechnic University: Social Science Edition, 7, 70-74.

[16] Mussweiler, T. (2003) Comparison Processes in Social Judgment: Mechanisms and Consequences. Psychological Review, 110, 472-489. http://dx.doi.org/10.1037/0033-295X.110.3.472

[17] Buunk, B.P., Wilmar, B. and Burnout, S. (2005) A Perspective from Social Comparisontheory. Journal of Experimental Social Psychology, 14, 201-209.

[18] Shipley, A. (2008) Social Comparison and Pro-Social Behavior: An Applied Study of Social Identity Theory in Community Food Drives. Psychological Reports, 102, 88-95. 
http://dx.doi.org/10.2466/pr0.102.2.425-434

[19] Cui, W. (2010) Research of Green Consumption Dynamic Mechanism Model. Tianjin University, Tianjin.

[20] Ottman, J. (1992) Sometimes Consumers Will Pay More to Go Green. Journal of International Consumer Marketing, 16, 12-120.

[21] Tesser, A. (2008) Toward a Self-Evaluation Maintenance Model of Social Behavior. Advances in Experimental Social Psychology, 21, 181-227. http://dx.doi.org/10.1016/S0065-2601(08)60227-0

[22] Festinger, L. (1957) A Theory of Social Comparison Processes. Human Relations, 5, 66-71.

[23] Martin, B. and Simintiras, A.C. (1995) The Impact of Green Product Lines on the Environment: Does What They Know Affect How They Feel? Marketing Intelligence and Planning, 13, 16-23. http://dx.doi.org/10.1108/02634509510088991

[24] Mussweiler, T., Ruter, K. and Epstude, K. (2004) The Ups \& Downs of Social Comparison: Mechanisms of Assimilation \& Contrast. Journal of Personality \& Social Psychology, 87, 832-844. http://dx.doi.org/10.1037/0022-3514.87.6.832

[25] Shamdasani, P., Chon-Lin, G. and Richmond, D. (2003) Exploring Green Consumers in an Oriental Culture: Role of Personal and Marketing Mix. Advances in Consumer Research, 20, 488-493.

\section{Submit or recommend next manuscript to SCIRP and we will provide best service} for you:

Accepting pre-submission inquiries through Email, Facebook, LinkedIn, Twitter, etc. A wide selection of journals (inclusive of 9 subjects, more than 200 journals)

Providing 24-hour high-quality service

User-friendly online submission system

Fair and swift peer-review system

Efficient typesetting and proofreading procedure

Display of the result of downloads and visits, as well as the number of cited articles

Maximum dissemination of your research work

Submit your manuscript at: http://papersubmission.scirp.org/

Or contact tel@scirp.org 